\title{
"THE ONE-EYED ARE KINGS": IMPROVING CONGRESS'S ABILITY TO REGULATE THE USE OF JUDICIAL RESOURCES
}

\author{
LARRY KRAMER*
}

\section{I \\ Introduction: The Need for Better Planning}

\section{A. The Intractable Problem of Caseload Growth in the Federal Courts}

A broad consensus exists today on the need to reduce the federal caseload. There are, to be sure, a few holdouts protesting that things really are not all that bad (motivated partly, I suspect, by fears that reform may make them worse). But a fair-minded evaluation of the federal docket makes it difficult to resist the conclusion that something should be done. Apart from brief periods in the 1920s and 1940s when case filings suddenly increased and then decreased, ${ }^{1}$ caseload growth was moderate in the district courts and virtually nil in the courts of appeals from the late 1800 s until approximately $1960 .^{2}$ The period beginning 1958-62, however, marks a sharp turning point. Since then, caseload growth has been consistently very large in both trial and appellate courts, and it shows no signs of abating. ${ }^{3}$

Let me recount some statistics. Although the bottom line is familiar, the numbers are striking enough to bear repetition. ${ }^{4}$ Since 1960 , case filings have

Copyright $\odot 1991$ by Law and Contemporary Problems

* Professor of Law, University of Chicago Law School.

I am grateful to Al Alschuler, Akhil Amar, Robert Bone, David Currie, Charles Geyh, John Langbein, Michael McConnell, and Judith Resnik for comments on an earlier draft. Research assistance for this paper was provided by the Scaife Foundation, the Kirkland \& Ellis Professorship, and the Leonard Sorkin Faculty Fund.

1. These "bulges" in case filings are attributable to Prohibition and World War II price control legislation. See Keith O. Boyum \& Sam Krislov, eds, Forecasting the Impact of Legislation on Courts 12 (Academy Press, 1980) (Committee on Law Enforcement and the Administration of Justice).

2. See id; Richard Posner, The Federal Courts: Crisis and Reform 65-66 (Harvard U Press, 1985).

3. See Posner, The Federal Courts at 65-66 (cited in note 2); Judicial Conference of the United States, Report of the Federal Courts Study Committee 4-9 (April 2, 1990). Unlike the two earlier bulges, the rapid growth of the past 30 years remains largely unexplained. See Marc Galanter, The Life and Times of the Big Six; Or, the Federal Courts Since the Good Old Days, 1988 Wis L Rev 921.

4. The figures in the text are from the Annual Reports of the Director of the Administrative Office of the United States Courts. These data are analyzed in greater detail in Part I of the Report to the Federal Courts Study Committee of the Subcommittee on the Role of the Federal Courts and Their Relation to the States ("Subcommittee Report on the Role of the Federal Courts"), published separately as Part III of the Report of the Federal Courts Study Committee (cited in note 3). See also Erwin Chemerinsky \& Larry Kramer, Defining the Role of the Federal Courts, 1990 BYU L Rev 67, 67 n 1; Posner, The Federal Courts at chs 3, 4 (cited in note 2). 
increased by 250 percent in the district courts and 900 percent in the courts of appeals. This growth has been partially offset by new judicial appointments, but filings per judge increased during the same period by 55 percent in the district courts and 336 percent in the courts of appeals. Measured in terms of difficulty, this growth reflects a substantial increase in the workload of federal judges. In the district courts, for example, the amount of time each judge must spend in court has increased by 35 percent. A more refined measure, "weighted" case filings (which adjust raw caseload data to account for the relative amount of time required for different cases), indicates that the total workload of each district court judge doubled between 1962 and 1988. In the courts of appeals, the increase has been still more dramatic. Terminations after oral argument or the submission of briefs have increased by more than 600 percent since 1960. Even taking new appointments into account, the number of appeals heard by each court of appeals judge has more than tripled. And while the percentage of cases decided by a signed, published opinion decreased from 74 percent to 38 percent, the number of such opinions increased from thirty-one per judge in 1960 to more than forty-six in 1988.

Federal judges have responded to this growth by working longer hours and delegating more work to non-judicial personnel, especially law clerks and staff attorneys. ${ }^{5}$ A recent survey of federal judges reports pervasive complaints about hours, stress, and the difficulty of finding time to do the job well. ${ }^{6}$ It is temptirg to dismiss such complaints as self-aggrandizing, but their frequency and vehemence suggests that something more is involved-as does the surprisingly large number of judges who indicate that they might not accept a nomination if it were offered again. ${ }^{7}$

Federal judges also have responded to caseload growth by changing the way they process their cases. Important innovations in the district courts include the development of case management techniques and the proliferation of alternative dispute resolution ("ADR"). In the courts of appeals, significant developments include decreasing the number and length of oral arguments and deciding more cases by summary order.

A push for legislation to address caseload growth began almost simultaneously with the increase in filings. ${ }^{8}$ In recent years, this reform

5. See Subcommittee Report on the Role of the Federal Courts at 40-91 (cited in note 4).

6. Id at 40-46.

7. Id at 91. The survey conducted by the Federal Courts Study Committee found that if offered the job again, $57 \%$ of courts of appeals judges would have to "give the matter careful thought," while $9 \%$ would decline the offer. Id.

8. The American Law Institute began its study of the allocation of jurisdiction between state and federal courts in 1960, after Chief Justice Warren expressed concern for the "constant upward trend in the total volume" of cases. Study of the Division of Jurisdiction Between the State and Federal Courts ix (Am Law Inst, 1969). Judge Friendly wrote his influential book calling for reform to control the "explosion" of federal court litigation in 1973. Henry J. Friendly, Federal Jurisdiction: $A$ General View (Columbia U Press, 1973). Chief Justice Burger identified the need for caseload relief early in his tenure and pressed this theme throughout his term as head of the judicial branch. See, for example, Warren Burger, The State of the Federal Judiciary, 1972, 58 ABA J 1049 (1972). 
movement has been dominated by calls for more widespread use of case management and ADR-an ironic attempt to turn a symptom of the problem into its solution. The caseload growth of the past thirty years is a matter of concern because it has compromised the quality of adjudication in the federal courts. But insinuating judges into the dispute resolution process with an independent agenda of docket reduction, reducing procedural protections based on judges' uninformed or only partly informed impressions of a case, and deciding appeals without oral argument or a reasonably thorough explanation hardly advance the cause of justice. Indeed, the fact that caseload growth has made such responses seem reasonable is itself strong evidence that something should be done to relieve the pressure.

In any event, even aggressive case management and ADR offer only modest hopes for docket relief. For example, there is evidence that case management produces faster dispositions, ${ }^{9}$ but no evidence that it is costeffective. ${ }^{10}$ Case management requires relatively intense judicial involvement, particularly in the early stages of litigation, and, as Judith Resnik has said, "the judge's time is the most expensive resource in the courthouse."11 Because most cases are resolved without trial anyway, judges may spend time managing cases that would have settled without the judge, and the result may be a net waste of judicial resources. ${ }^{12}$ The same also may be said of ADR. Indeed, critics of ADR suggest that it may actually invite litigation by depriving potential litigants of authoritative decisions. ${ }^{13}$ There is reason to doubt this claim since, if anything, we already have too much precedent, but the important point is simply that little empirical evidence supports the claim that ADR saves judicial resources. As with case management, ADR's implications for the federal docket are uncertain at best.

Another way to reduce the workload of federal judges might be to appoint more of them. Until recently, adding judges was Congress's favorite response to caseload growth. ${ }^{14}$ But this approach may finally have run its course due to mounting opposition from judges. ${ }^{15}$ Moreover, while some of this opposition

9. See generally Steven Flanders, Case Management and Court Management in United States District Courts (Fed Jud Ctr, 1977).

10. See D. Marie Provine, Settlement Strategies for Federal District Judges 38-40 (Fed Jud Ctr, 1986) (evaluating studies on case management and finding the evidence that these save judicial time inconclusive).

11. See Judith Resnik, Managerial Judging, 96 Harv L Rev 374, 423 (1982).

12. See Marc Galanter, The Quality of Settlements, 1988 J Dispute Res 56, 73.

13. See, for example, Richard Posner, Summary Jury Trials, 53 U Chi L Rev 366, 382-88 (1986); William T. Gallagher, The Transformation of Justice: Hofrichter's Neighborhood Justice and Harrington's Shadow of Justice, 13 L \& Soc Inquiry 133, 134 (1988) (collecting studies).

14. There were 321 federal judges in 1960. Congress then created new positions in 1961, 1966, $1968,1978,1982,1983$, and 1984. By 1970, there were 479 federal judges; by 1980 , the number had grown to 626 . There are now more than 700 judges filling 743 authorized judgeships in the district courts and courts of appeals. See Chemerinsky \& Kramer, 1990 BYU L Rev at $68 \mathrm{n} 2$ (cited in note 4); Subcommittee Report on the Role of the Federal Courts at $94 \mathrm{nl}$ (cited in note 4).

15. The usual argument against appointing more federal judges is that this will diminish the quality of the federal judiciary by straining the effectiveness of the appointment process, depreciating the prestige of being a federal judge, generating too much administrative work, and reducing collegiality. See Friendly, Federal Junisdiction at 28-31, 39-41 (cited in note 8); Jon O. Newman, 
may be self-serving, Congress should exercise caution before creating many more judgeships. The federal judicial system has evolved so that we now rely on the courts of appeals for final decisions on most legal questions. It was not always so. Under the Judiciary Act of 1789, the Supreme Court decided virtually all appeals. By the $1860 \mathrm{~s}$, growth in the federal docket led to complaints that lack of appellate capacity left individual trial judges with too much unreviewable discretion. Although this problem had become quite serious by the end of Reconstruction, political difficulties delayed a solution until 1891, when Congress enacted the Evarts Act, creating the present courts of appeals. ${ }^{16}$

The strategy adopted in the Evarts Act is based on the recognition that effective appellate review requires a relatively small court of appeals to maintain consistent and uniform positions with respect to the trial courts. Because the federal caseload was too large for a single appellate court, Congress compromised by establishing a few intermediate appellate courts with jurisdiction over relatively large areas. Each court was small enough to assure reasonable uniformity within its jurisdiction. And as long as the number of circuits was kept small, the Supreme Court could resolve conflicts among the courts of appeals.

Enlarging the courts of appeals undermines this scheme. Each new judge increases geometrically the number of different panels that may hear a case. Other things being equal, more panels mean more uncertainty about how the court is likely to rule in any particular case, thereby encouraging more appeals and making intra-circuit conflicts more likely. At the same time, as the court grows, it becomes more difficult to hear cases en banc and to obtain a majority in cases that are heard by the whole court. Before long, even en banc review no longer ensures uniformity. Pressure then grows to divide the circuit. But that merely increases the likelihood of splits among the circuits, shifting responsibility for maintaining uniformity back to the Supreme Court, which already has its hands full.

These concerns are not hypothetical. Problems of size and maintaining intra-circuit uniformity already have led to the division of the Fifth Circuit and may soon do the same to the Ninth. To be sure, some commentators argue that problems of managing a large circuit have been exaggerated, ${ }^{17}$ but not even these commentators suggest that creating more courts of appeals as large as the Ninth Circuit is desirable. Yet at current growth rates, the number of new appointments would soon make the present Ninth Circuit seem small. If caseload pressures are to be relieved by appointing more judges, however, the only alternative to giant courts of appeals is more courts

Restructuring Federal Jurisdiction: Proposals to Preserve the Federal Judicial System, 56 U Chi L Rev 761, 76267 (1989). I have explained elsewhere why I believe that these arguments are overstated. Chemerinsky \& Kramer, 1990 BYU L Rev at $69-72$ (cited in note 4).

16. Act of March 3, 1891, 26 Stat 826, codified at 46 USC $\S 46$ (1988). See Felix Frankfurter \& James Landis, The Business of the Supreme Court 69-102 (Macmillan, 1927).

17. See, for example, Joe S. Cecil, Administration of Justice in a Large Appellate Court: The Ninth Circuit Innovations Project (Fed Jud Ctr, 1985). 
of appeals-an uninviting prospect that simply shifts pressure back to the court least able to handle it, the Supreme Court. Either way, the effectiveness of appellate review is weakened. ${ }^{18}$

A third way to reduce the federal workload is to reduce the scope of federal jurisdiction by eliminating unimportant categories of cases so that judges can devote more time to the cases that remain. The strong opposition to even the most modest recommendations of the Federal Courts Study Committee $^{19}$ (with the consequent likelihood that only insignificant, technical recommendations will be enacted ${ }^{20}$ ) underscores the difficulty with this approach. There may be widespread support for reducing the scope of federal jurisdiction, but there are numerous ways to do this and strong opposition to each one. Because interest groups with narrow, focused demands can often overcome more diffuse support for broad reform, ${ }^{21}$ none of these solutions has been adopted. Hence, supporters of diversity jurisdiction argue that this jurisdiction is essential and suggest that Congress reduce the federal docket by repealing rights like those conferred in the Federal Employer's Liability Act ${ }^{22}$ and the Jones Act. ${ }^{23}$ Lawyers for railroad employees and seamen (and their unions) say that these rights are too important to abandon and recommend instead that Congress concentrate on reducing frivolous prisoner petitions. Civil rights advocates respond that prisoners must have access to federal courts and counsel Congress to eliminate diversity. And so the buck gets passed around and around; in the end nothing is done. ${ }^{24}$

18. Another solution is to adopt one of the proposals for an intermediate court to resolve conflicts among the circuits. A full discussion of the complications attending this solution is beyond the scope of this article, but the literature on the subject indicates that the various proposals to create such a court all have significant problems. See, for example, Commission on Revision of the Federal Appellate System, Structure and Internal Procedures: Recommendation for Change, 67 FRD 195 (1975); Federal Judicial Center, Report of the Study Group on the Caseload in the Supreme Court, 57 FRD 573 (1972).

19. Congress created a 15 -member Federal Courts Study Committee in Title 1 of the Judicial Improvements and Access to Justice Act of 1988, Pub L No 100-702, 102 Stat 4642, codified chiefly in scattered sections of 28 USC, ordering it to "examine problems and issues currently facing the courts of the United States" and "develop a long-range plan for the future of the Federal judiciary 102 Stat 4644. The committee's report, submitted to Congress on April 2, 1990, contains a broad range of recommendations about restructuring the federal courts and modifying federal jurisdiction. See Report of the Federal Courts Study Committee (cited in note 3).

20. See, for example, Congress Cool to Proposals to Ease Load on Courts, 48 Cong Q 1073 (April 7, 1990).

21. See, for example, Kay Lehman Schlozman \& John T. Tierney, Organized Interests and American Democracy 315 (Harper \& Row, 1986); Daniel A. Farber \& Philip P. Frickey, The Jurisprudence of Public Choice, 65 Tex L Rev 873, 887 (1987).

22. 45 USC $\$ \S 51$ et seq (1988).

23. Merchant Marine Act of 1920,41 Stat 988 , codified at 46 USC $\$ 597$ (1988).

24. Judges are not entirely free of self-serving opposition to useful reform. Concern for prestige and the desire for a varied docket lead most Article III judges to oppose the creation of special courts with limited jurisdiction. See, for example, Report of the Proceedings of the Judicial Conference of the United States 60 (1986) ("The Judicial Conference has consistently opposed the establishment of specialized courts in the judicial branch.'); Carroll Seron, Court Reorganization and the Politics of Reform: The Case of the Bankrupicy Court, in Philip R. Dubois, ed, The Politics of Judicial Rejorm 94-95, 97 (Lexington Books, 1982). This opposition is at least partly responsible for discouraging even modest experiments with an approach to adjudication that works well everywhere else in the world. 
In any event, even if Congress could agree on what cases to remove from the federal docket, this would provide only a short-term solution. The federal docket necessarily evolves with the nation's substantive goals, and the business of the federal government changes too fast and is too controversial for federal jurisdiction to remain stable. No one foresaw in the $1850 \mathrm{~s}$ that federal courts would be needed to protect myriad new federal rights by the end of the 1860s. No one thought in the years before the eighteenth amendment that a huge investment of federal judicial resources would be necessary to enforce Prohibition, just as no one foresaw when the amendment was ratified how short its life would be and how quickly this business would disappear. Of more recent vintage, I doubt that many people in the mid1950 s anticipated how important civil rights cases would become. And no one would have predicted as recently as five years ago that we would begin a "war on drugs" requiring a massive investment of federal judicial resources (just as no one can predict how long this demand will last). Our national priorities change so quickly that about the only thing of which we can be sure is that tomorrow's docket will look very different from today's. New laws will be enacted; unforeseen problems will arise; new accommodations will be required.

The lesson is not that the situation in the federal courts is hopeless. On the contrary, after more than a quarter century, we may finally have reached the point where Congress will adopt some combination of these three approaches-informal procedures, additional judgeships, and reduced jurisdiction-to relieve the caseload burden. But the forces that delayed congressional action for so long will not suddenly disappear. If any lesson is to be drawn from the analysis above, it is that the dynamics of judicial reform discourage Congress from acting until problems become serious (something that is true of many other areas as well). Assuming, then, as seems likely, that the federal docket continues to grow and change, we will soon be back in the same position.

We can, however, delay the recurrence of these problems and perhaps reduce their severity by encouraging Congress in making judicial resources available more efficiently. To this end, I propose to establish an agency to assist Congress to make informed decisions about how to structure federal jurisdiction when it enacts new legislation. I make no extravagant claims about the benefits of this proposal. It will not solve all our problems. Pressures will still build as new laws are enacted, old laws are reinterpreted, and other changes affect the amount of litigation. But better planning as we go along may provide modest benefits by deferring these pressures and minimizing the costs to everyone in the meantime.

\section{B. Groping in the Dark: Causes and Effects of Inadequate Planning}

There is currently no formal mechanism to assure that judicial resources are utilized efficiently. The closest thing that now exists in Congress is the 
Office of the Law Revision Counsel in the House of Representatives. ${ }^{25}$ But while this body's statutory mandate is broad enough to permit it to serve a planning function, ${ }^{26}$ lack of resources has limited it to the largely ministerial task of keeping the United States Code up to date. As a result, Congress gives little systematic consideration to the impact of new legislation on the federal courts. What planning takes place is done haphazardly in committee, and on those occasions when serious consideration is given to structuring federal jurisdiction, questions of efficiency are seldom in the foreground. ${ }^{27}$

Entities with some planning responsibilities do exist in both the executive and judicial branches, namely, the Office of Legislative Affairs in the Department of Justice and the Office of Legislative and Public Affairs in the Administrative Office. But these offices lack the resources and expertise to conduct the necessary analyses. What assistance they do provide thus tends to be sporadic and impressionistic when the necessary assistance should be systematic, technical, and comprehensive. Moreover, because these agencies are not part of Congress, they have a limited ability to demand attention and are often treated more like lobbies than helpmates. In fact these offices are lobbies, seeking to advance the particular agendas of the executive and judicial branches (which do not necessarily include making optimal use of judicial resources in implementing a particular substantive law ${ }^{28}$ ).

The absence of an agency capable of, and responsible for, evaluating judicial jurisdiction under proposed legislation and disseminating the relevant information to members of Congress occasionally leads to spectacular failures, such as the National Childhood Vaccine Injury Act of 1986. ${ }^{29}$ This legislation gave claimants a right to compensation for illness or death resulting from vaccination. Apparently, no one in Congress considered the need for special arrangements to adjudicate cases arising under the new law; adjudication was left to the district courts. The resulting flood of litigation

25. See Office of the Law Revision Counsel, 2 USC $\S \S 285-285 \mathrm{~g}$ (1988).

26. 2 USC $\S 285 \mathrm{~b}$ lists among the office's functions the duty to submit a revision of the laws to remove "ambiguities, contradictions, and other imperfections both of substance and of form," and to provide the Judiciary Committee "with such advice as the committee may request in carrying out its functions with respect to the revision and codification of the Federal statutes."

27. See Geoff Gallas, Judicial-Impact Statements: Administration, Behavior, and Politics, in Philip Dubois, ed, The Politics of Judicial Reform 151 (Lexington Books, 1982); Cornelius M. Kerwin, JudicialImpact Statements and Court Management: And Never the Twain Shall Meet, in Philip Dubois, ed, The Analysis of Judicial Reform 171 (Lexington Books, 1982) ("Never the Twain Shall Meet"); Robert P. Davis \& Paul Nejelski, Justice Impact Statements: Determining How New Laws Will Affect the Courts, 62 Judicature 18, 19 (1978); Burger, 58 ABA J at 1049 (cited in note 8). See generally Hearings on the State of the Judiciary and Access to Justice before the Subcommittee on Courts, Civil Liberties, and the Administration of Justice of the House Committee on the Judiciary, 95th Cong, 1st Sess (1970) (CIS H No 521-8, Govt Printing Office, 1977).

28. For example, while the Department of Justice represents the United States in the district courts, the Internal Revenue Service handles cases in the Tax Court; this gives the department an interest in preserving or extending district court jurisdiction over refund actions. Similarly, as noted above, concerns for prestige and the desire for a varied caseload lead most Article III judges to oppose the creation of limited courts of special jurisdiction even when such courts make sense in terms of overall resource allocation. See generally Seron, Court Reorganization and the Politics of Reform (cited in note 24) (discussing opposition to giving bankruptcy judges Article III status).

29. Pub L No 99-660, 100 Stat $3743,3755-84$ (1986), codified at 42 USC $\$ 300 a a$ (1988). 
proved difficult to handle. It took more than a year to secure legislative relief, with Congress eventually shifting a large part of the burden to the Claims Court. ${ }^{30}$

Most inefficiencies in the use of judicial resources are less dramatic. Some problems, for example, derive from Congress's failure to resolve simple housekeeping matters, such as whether a law applies retroactively or confers a private cause of action. ${ }^{31}$ These statutory gaps create uncertainty and foster needless litigation. Other problems have more fundamental causes. Congress may vest concurrent jurisdiction in several courts, creating forum shopping opportunities that generate conflicting decisions and additional litigation. ${ }^{32}$ Or Congress may make an agency's decisions reviewable in both the district courts and the courts of appeals when a single tier of Article III review would suffice. ${ }^{33}$ Or Congress may fail to anticipate the amount or nature of litigation likely to arise under particular legislation and so fail to provide adequate judicial resources. Standing alone, the consequences of such failures are seldom striking enough to elicit the same quick response as the Vaccine Injury Act. But the cumulative effect of these incremental inefficiencies may be great and may needlessly exacerbate federal caseload problems.

One may, of course, legitimately ask whether the same forces that stymie judicial reform legislation will similarly frustrate planning. The difference is that, rather than relating to separate legislation for the courts, planning will be part of the process of formulating particular substantive legislation. Attempts to promote judicial reform through direct legislation facilitate concentrated opposition. By instead offering discrete recommendations concerning pending legislation, planning will take place in a context in which the forces that ordinarily impede change have largely been overcome.

The process that determines whether and when particular substantive legislation may be enacted is complex and unpredictable. Policy analysts talk about "streams" that flow through a decisionmaking structure: one stream consists of problems; another consists of solutions, often generated by persons whose job is to develop such ideas and not necessarily in direct response to a particular problem; still a third stream consists of participants who drift in and out of government advocating pet problems or solutions. ${ }^{34}$

30. See Robert A. Katzman, ed, Judges and Legislators: Toward Institutional Comity $7.8 \mathrm{n} 4$ (Brookings Inst, 1988).

31. See Hearings on S 1482 before the Subcommittee on Courts and Administrative Practice of the Senate Judiciary Committee, 100th Cong, 2d Sess 167 (1988) (statement of Stephen J. Markman).

32. See, for example, Friendly, Federal Jurisdiction at 161-71 (cited in note 8) (discussing problems with the trifurcated jurisdiction of the tax court, claims court, and district courts over tax cases); Larry Kramer, Jurisdiction over Civil Tax Cases, 1990 BYU L Rev 443 (same).

33. See Richard E. Levy, Social Security Disability Determinations: Recommendations for Reform, 1990 BYU L Rev 463; David P. Currie \& Frank I. Goodman, Judicial Review of Administrative Action: Quest for the Optimum Forum, 75 Colum L Rev 1, 23-39 (1975) (evaluating the Social Security Administration, the National Labor Relations Board, the Immigration and Naturalization Service, and the Benefits Review Board for longshoremen's and black lung cases).

34. See John Kingdon, Agendas, Alternatives, and Public Policies 90 (Little, Brown, 1984). 
As one group of commentators describes it, organizations like Congress are "a collection of choices looking for problems, issues and feelings looking for decision situations in which they might be aired, solutions looking for issues to which they might be the answer, and decision makers looking for work."35

Periodically, these separate streams come together. A problem is recognized, a solution is available, the political climate makes it the right time for change: a "policy window" opens, presenting an opportunity for action on a given initiative. During this period, forces that ordinarily impede reform are at their weakest, and lawmakers are most open to ideas about how to make improvements. During this period, then, it becomes feasible to make recommendations about the most efficient way to structure federal jurisdiction for cases arising under the new legislation.

Several additional factors may help to create breathing room for intelligent planning while legislation is being formulated. First, while it is usually clear who wins and who loses under established legal practices, the likely implications of different forms of adjudication may be ambiguous before a law is enacted, weakening opposition to any particular form. Second, questions of procedure may not be central to the debate over new legislation, since attention will usually be focused on the substantive provisions of a proposed law.

While these considerations suggest that a planning agency could be effective, some obvious questions concerning methodology and feasibility must be addressed. A full evaluation of the proposal's merits thus requires a more thorough understanding of the agency's functions. Moreover, because there are different reasons for inefficient deployment of judicial resources, the proposed agency will have to undertake several tasks. The next section discusses these in greater detail.

\section{Functions of the Agency}

\section{A. Reviewing Proposed Legislation}

The primary function of a planning agency would be to assist the committees of Congress in preparing legislation. I already mentioned, for example, the problem of statutory omissions. Congress often fails to specify such matters as who can sue, what the proper limitations period is, whether state law is preempted, what types of relief are available, and other housekeeping matters. Sometimes, of course, these gaps are deliberate. Congress may leave aspects of a law unclear as a political compromise or because an issue that could not be resolved was not important enough to prevent passage of the legislation altogether. But there are also cases of oversight, and much needless litigation could be prevented by a preliminary review of legislation with an eye toward its administration by the courts.

35. Michael D. Cohen, James G. March \& John P. Olsen, A Garbage Can Model of Organizational Choice, 17 Admin Sci Q 1, 2 (1972). 
One simple method of avoiding inadvertent omissions is to devise a legislative checklist of frequently overlooked issues for use by the relevant congressional committees. ${ }^{36}$ Many items might be included on such a checklist. The Department of Justice produced a list of twelve. ${ }^{37}$ The Federal Courts Study Committee added six items to this list. ${ }^{38}$ It is easy, moreover, to think of still other issues that might be included: Are litigants entitled to a jury trial? Can federal courts enjoin inconsistent state proceedings? Is the states' sovereign immunity overridden? Is final action by administrators subject to judicial review, and, if so, in what court?

We do not, of course, need a new agency to examine proposed legislation to see whether it includes the provisions specified on a checklist. Both Houses of Congress created Offices of the Legislative Counsel to review proposed legislation for clarity of expression. ${ }^{39}$ Once a list is prepared, either of these offices or the relevant congressional committees or subcommittees could review legislation for inclusion of the relevant items.

We do, however, need someone to generate, refine, and update the checklist. This task may be more difficult than it appears. The lists prepared by the Department of Justice and the Federal Courts Study Committee, for example, are simultaneously overinclusive and incomplete. They are overinclusive in that many items, such as those pertaining to laws that create or utilize an administrative agency, are relevant only for certain kinds of legislation. At the same time, the proposed lists are incomplete because they overlook other issues that arise frequently in the same specialized contexts. In the administrative law context, for example, questions such as who has standing to sue or whether an agency may make de minimis exceptions are commonplace. ${ }^{40}$ It might therefore be useful to develop different lists for different kinds of legislation. The task of generating these lists (and keeping

36. This proposal has been made by others. See, for example, Hearings on S 1482 at 167 (cited in note 31); Katzman, Judges and Legislators at 183-84 (cited in note 30); Report of the Federal Courts Study Committee at 91-92 (cited in note 3).

37. The Justice Department's proposed checklist called for consideration of the following: (1) a civil statute of limitations; (2) retroactivity; (3) the availability of attorney's fees, and, if available, the terms under which a fee award would be proper; (4) preemption; (5) the mens rea necessary to establish criminal liability; (6) the advisability of a private cause of action; (7) severability; (8) a requirement to exhaust administrative remedies; (9) standards governing the assertion of personal jurisdiction; (10) a provision permitting arbitration; (11) definitions of key statutory terms; and (12) whether administrative proceedings should be formal or informal. See Hearings on $S 1482$ at $206-07$ (cited in note 31). See also Legal Impact Statement: One Proposal for Painless Court Reform (Dept of Justice Office of Legal Policy, Dec 1987) (discussing cases in which each of the listed items was a problem).

38. To the items listed in the Department of Justice proposal, the Federal Courts Study Committee added: (1) whether the proposed legislation would repeal or otherwise change the meaning of existing federal legislation; (2) whether state courts are to have jurisdiction and, if so, whether an action would be removable to federal court; (3) what types of relief are available; (4) whether a deadline for judicial action is necessary or reasonable; (5) whether there is a need to use multi-district panels; and (6) whether the statute applies to the territories, the District of Columbia, and Puerto Rico. Report of the Federal Courts Study Committee at 91-92 (cited in note 3).

39. 2 USC $\$ \S 275$ (Senate), 28 la (House) (1988).

40. For a list of statutory interpretation issues in the administrative context, see Cass $R$. Sunstein, Interpreting Statutes in the Regulatory State, 103 Harv L Rev 405, 476-93 (1989). 
them up to date as new issues arise and old ones fade in importance) could be delegated to the new agency-which could then either assume the additional responsibility of reviewing legislation for compliance or leave this task to some other body in Congress.

While useful, the task of administering a legislative checklist is less important than examining proposed legislation to make recommendations about structuring federal jurisdiction. The value of such recommendations was explained in Part I and hardly seems controversial. ${ }^{41}$ It is their feasibility that is debated. Some commentators argue that our ability to foresee demands for judicial services resulting from particular legislation is so limited that we should abandon the effort altogether.42 However, while the difficulties with projecting caseloads are real, we can still do a great deal of useful planning.

The debate over caseload forecasting began with a 1972 proposal by Chief Justice Burger to have all legislation accompanied by a "court impact statement" prepared by the reporting committee and indicating "how many more judges and supporting personnel will be needed to handle the new cases." 43 This proposal's relatively quick demise resulted in part from disillusionment with impact statements in other contexts, especially environmental law. ${ }^{44}$ For the most part, however, the Chief Justice's proposal failed because of methodological flaws. For example, a number of commentators argued that an across-the-board requirement for impact statements would simply become a pro forma exercise, producing "tedious and inconclusive work" of little value. ${ }^{45}$

More fundamentally, critics argued that we lack "the basic theoretical and empirical knowledge" necessary to make the estimates called for by Chief

41. See also Report of the Department of Justice Committee on Revision of the Federal Judicial System, The Needs of the Federal Courts 16-17 (1977) ("an agency is needed to project trends, foresee needs and propose remedial measures") ("The Bork Report"); Kerwin, Never the Twain Shall Meet at 171 (cited in note 27) (successful use of forecasting "would constitute one of the most important reforms in the history of the federal-court system"); Jerry Goldman, Richard L. Hooper \& Judy A. Mahaffey, Caseload Forecasting Models for Federal District Courts, 5 J Legal Stud 201,203 (1976) ("forecasts can only improve the process of translating demand for services into resource availability"). 1).

42. See, for example, Boyum \& Krislov, Forecasting the Impact of Legislation on Courts (cited in note

43. See Burger, 58 ABA J at 1050 (cited in note 8).

44. See Boyum \& Krislov, Forecasting the Impact of Legislation on Courts at 21-23 (cited in note 1) (problems with inflation, economic, and environmental impact statements suggest caution before adopting judicial impact statements); Davis \& Nejelski, 62 Judicature at 20-21 (cited in note 27) (same with less pessimistic conclusion).

45. See, for example, Boyum \& Krislov, Forecasting the Impact of Legislation on Courts at 4, 21 (cited in note 1): Paul Nejelski, Judicial Impact Statements: Ten Critical Questions We Must Not Overlook, 66 Judicature 122, $124-25$ (1982); Gallas, Judicial-Impact Statements at 155 (cited in note 27) ("the indiscriminate judicial-impact statement methodology is an example of technocratic overkill and grandiose thinking, modes of action and thinking that characteristically hinder policy implementation"). 
Justice Burger. ${ }^{46}$ Just identifying the factors that affect case filings under particular legislation can be difficult. What, for instance, determines the number of employment discrimination cases? Racism is obviously important, but so are a multiplicity of other factors, including the difficulty of finding alternative employment, the availability of unemployment benefits, societal perceptions of discrimination, the efficacy of alternative state law remedies, the number of lawyers, and so on. Second, even if we successfully identify the relevant factors, we must develop a model that accurately captures their relationship to case filings. Of the factors just listed, which are more and which are less important to case filings? How much more or less important? Third, forecasts rely on past events to make assumptions about the future, but there is no guarantee that past trends will continue. If new circumstances arise or factors affecting past trends change, past experience may turn out to be a poor guide. ${ }^{47}$

These difficulties are compounded by three additional problems. First, forecasting litigation requires making predictions about the behavior of potential litigants, their lawyers, judges, court personnel, and other government regulators. Consider, for example, the following questions, all relevant in predicting the amount of litigation likely to arise under a new law: How widespread are transactions that could give rise to liability? What proportion of potential plaintiffs will consult a lawyer and pursue a lawsuit?48 What proportion of defendants will settle before litigation is commenced? Will lawyers be reluctant to bring this type of litigation? Will judges and other court personnel put these cases on the fast track or send them to the back of the court queue? Although the answers to these questions may vary for different laws and different affected groups-with obvious implications for forecasting-our ability to make such predictions is limited.

Second, regulated entities learn from and react to the conditions created by new laws. One might assume, for example, that as a new law succeeds, the number of transactions that give rise to litigation will decline-and with that the number of lawsuits will also decline. But if deterrence results from successful lawsuits, this very success may encourage plaintiffs to sue in a

46. Boyum \& Krislov, Forecasting the Impact of Legislation on Courts at 3 (cited in note 1). The problems identified in the following paragraphs are drawn principally from Boyum and Krislov, and from Kerwin, Never the Twain Shall Meet (cited in note 27).

47. Furthermore, the factors upon which predictions are based may themselves be based on predictions. Predicting the number of available lawyers or the size of welfare benefits can be as complicated as predicting caseloads. Yet any caseload forecast will only be as good as these underlying estimates.

48. There are wide variations in how likely someone is to resort to litigation for different claims. One study showed that only $1 \%$ of those who believed they had suffered job discrimination consulted a lawyer; this compares to $12 \%$ of those who had problems with their landlords, $11 \%$ of those who believed their constitutional rights were violated, $23 \%$ of those whose children were injured, $36 \%$ of those who had suffered personal injuries, and $70 \%$ of those who were involved in a divorce. See Barbara A. Curran \& Frances O. Spalding. The Legal Needs of the Public 83-84, Table 6.3 (Am Bar Found, 1974). See generally William L. R. Felstiner, Richard L. Abel \& Austin Sarat, The Emergence and Transformation of Disputes: Naming, Blaming, Claiming . . , 15 L. \& Society Rev 631 (1980-81) (developing a framework to understand the emergence of lawsuits). 
larger proportion of the potential cases. The law may thus deter without a corresponding decrease in the number of lawsuits. Similarly, Congress may try to reduce the number of filings by raising the amount in controversy required for jurisdiction. But if the parties can simply inflate their damages claims (because, for instance, elements of damages like pain and suffering or punitive damages are not easily quantifiable), the number of cases may decline very little or not at all.49

Finally, the factors relevant to making predictions are interactive: predicting what will happen to one may depend on what happens to another. The level of unemployment benefits may be affected by the level of unemployment; perceptions about whether discrimination is widespread may affect attitudes toward racism; state law remedies may be created or altered in response to federal remedies. Such interactions are especially common with respect to the behavioral considerations mentioned above. The desire of clients to pursue litigation is obviously influenced by whether lawyers are encouraging, and lawyers' attitudes are just as obviously affected by how receptive judges seem to be. Legal subsystems also interact in ways that complicate the process of making predictions. By increasing administrative demands on assigned counsel systems, for example, the Speedy Trial Act affected programs established a decade earlier in the Criminal Justice Act. ${ }^{50}$ This act may also have had a pervasive effect on civil litigation, requiring judges to devote more time to criminal cases and thereby creating new delays in obtaining a civil trial.

Do these problems make caseload planning impossible? I do not believe so. To begin with, the problems identified apply mostly to proposals that, like Chief Justice Burger's, require quantifying expected filings. But quantitative analysis is not the only useful kind of planning, nor is it even the most important kind. There is also "qualitative resource estimation," 51 which offers policymakers guidance on the likely forms of litigation under proposed legislation in ways that do not require the level of precision needed for Chief Justice Burger's impact statements. Rather than indicate how many additional judges or support personnel Congress should appoint, qualitative analysis addresses such questions as: Which court or courts should have jurisdiction? Should Congress rely wholly or partly on administrative adjudication? Should it create a specialized tribunal? Are special procedures needed or desirable? By deepening lawmakers' understanding of the general contours of expected litigation, qualitative analysis enables them to choose the most effective and efficient way to structure federal jurisdiction without the need for numerical forecasts.

49. See Larry Kramer, Diversity Jurisdiction, 1990 BYU L Rev 97, 99.

50. Cornelius M. Kerwin, Judicial Implementation of Public Policy: Judges and Legislation for the Courts, 16 Harv J Leg 415, 438 (1979) (Speedy Trial Act, 18 USC $\$ 3161$ (1988) (enacted in 1984); Criminal Justice Act, 18 USC $\$ 3006$ A (1988) (enacted in 1975)).

51. See Cornelius M. Kerwin, David Kochler \& John Dawson, Resource Estimation, Implementation, and Policy Optimization, 3 Policy Stud J 1070, 1070-73 (1980). 
A few illustrations should clarify the nature of this analysis. In Part I, I offered as an example of inefficient deployment of judicial resources the decision to subject an administrative agency's decisions to two tiers of Article III review when one could be made sufficient. This example describes the system of reviewing Social Security disability determinations. ${ }^{52}$ In 1972, Congress enacted legislation bringing several welfare programs, including the new federal Supplemental Security Income program, under the jurisdiction of the Social Security Administration. ${ }^{53}$ Recognizing that the number of administrative determinations under this scheme would be enormous, ${ }^{\mathbf{5 4}}$ Congress wisely decided not to permit direct appeals from the agency to the courts of appeals. Instead, Congress provided a first tier of review in the district courts, taking advantage of these courts' greater capacity in order to screen out many appeals. ${ }^{55}$

In adopting this strategy, Congress overlooked some pertinent considerations. Social security appeals are typically fact-bound and often turn on complex disputes involving technical, medical, or vocational questions. General jurisdiction judges have no special expertise in these areas. Even the legal issues involved in disability determinations are often the sort of technical matters on which courts normally defer to agency expertise. To make matters worse, many district judges apparently believe that a large percentage of social security appeals are frivolous. Between this belief and their heavy caseload, few judges are willing to devote time to sifting through these difficult records for error. The problems are further exacerbated by institutional weaknesses that make district courts ill-suited for appellate review:56 several days of the week must be devoted to conducting trials, and most of the remaining time is needed for related matters. Review of disability claims records is thus either overlooked or shunted off to clerks, staff attorneys, or equally unenthusiastic magistrates. In the end, rather than make a serious effort to understand the issues, many judges simply invoke the easy solution of reversing at the first sign of something fishy and remanding for the agency to make a better record. ${ }^{57}$

Full consideration of these factors might have led Congress to try a different strategy. For example, Congress might have established a specialized tribunal to hear first level appeals, with further review at the discretion of the courts of appeals or limited to questions of law. Because the

52. Unless otherwise indicated, my discussion of the Social Security disability claims process is drawn from Levy, 1990 BYU L Rev at 467 (cited in note 33), and Subcommittee Report on the Role of the Federal Courts at 285-353 (cited in note 4).

53. Social Security Amendments of 1972, 42 USC $\$ 1614$ (1972).

54. In any given year, between 200,000 and 300,000 cases are heard by an administrative law judge; 50,000 to 100,000 of these cases also require hearings before the Appeals Council of the Social Security Administration. See Levy, 1990 BYU L Rev at 481 (cited in note 33).

55. See Currie \& Goodman, 75 Colum L Rev at 24-25 (cited in note 33).

56. The institutional difficulties of appellate review in the district courts were explained to me by Judge Judith Keep of the United States District Court for the Southern District of California.

57. See Jerry L. Mashaw, et al, Social Security Hearings and Appeals 132-33 (Lexington Books, 1978). 
new tribunal's docket would consist entirely of disability claims, its judges would acquire the familiarity and expertise necessary to understand the difficult factual disputes at the heart of most disability cases. In addition, the enhanced authority and prestige of such a court would attract the ablest specialists in the disability field, further improving the quality of justice. Such a court could thus dispose of cases more efficiently and produce greater uniformity of results while affording claimants a more thorough examination of their claims than is currently provided by federal district judges. ${ }^{58}$

The question whether to channel Social Security appeals to a specialized court or to the district courts is, of course, more complicated than this brief discussion suggests. A more complete analysis, which is beyond the scope of this article, has been done elsewhere. ${ }^{59}$ But the very complexity of the question helps make my point that we need a permanent body whose job is to make recommendations about structuring jurisdiction. On the one hand, while sometimes controversial, this kind of analysis is plainly feasible and, as the example suggests, has enormous potential benefits. On the other hand, the task cannot be done ad hoc by persons who are not fully versed in the difficulties involved.

Another example of qualitative analysis comes from an article by Professor John Donohue, a participant in this symposium, and Peter Siegelman of the American Bar Foundation. ${ }^{60}$ Discussing the adjudication of employment discrimination disputes under Title VII of the Civil Rights Act of 1964, Donohue and Siegelman describe how the typical case has changed over the years. Whereas in the early years most Title VII suits challenged hiring policies based on allegations of an unlawful pattern and practice, more recently the typical case has been an individual claim for wrongful discharge or failure to promote. This shift may be explained by the success of the statute: as more protected workers enter the workforce, more opportunities arise for acts that may be challenged as discriminatory. Moreover, because a single hiring action may create employment opportunities for many workers, the growth in individual disparate treatment claims has been geometric relative to hiring actions. Cases challenging hiring practices outnumbered termination cases by 50 percent in 1966 ; by 1985 , the ratio was reversed by more than six to one. ${ }^{61}$

58. Relying on essentially these justifications, the Federal Courts Study Committee recommended that Congress create a "Court of Disability Claims." See Report of the Federal Courts Study Committee at 55.57 (cited in note 3). Unfortunately, and for many of the reasons discussed in Part I, the prospects that Congress will follow this recommendation are slim. See notes 19-24 and accompanying text. I believe that the recommendation would have had a better chance had it been made when Congress first established the disability claims process.

59. See authorities cited in note 52. For a different, though not unsympathetic view, see Mashaw, et al, Social Security Hearings and Appeals at 146-50 (cited in note 57); Jerry L. Mashaw, Bureaucratic Justice 185-209 (Yale U Press, 1983).

60. See John Donohue \& Peter Siegelman, The Changing Nature of Employment Discrimination Litigation, 43 Stan L Rev 983 (1991).

61. Id at 1015-21. 
These factors were available for analysis when Title VII was enacted. Had Congress considered them, it might have structured litigation under the law differently. For example, rather than have all actions brought in federal court, Congress might have given the Equal Employment Opportunity Commission ("EEOC") power to adjudicate individual wrongful discharge claims, perhaps using the adjudication of similar claims by the National Labor Relations Board as a model. The federal courts still would have been available to decide cases with broad implications for employment policy, but the agency could have decided the more routine disputes between an employee alleging that his or her discharge was invidiously motivated and an employer claiming that the discharge was legitimate. Such an allocation of authority might have prevented or reduced the influx of Title VII cases into the federal courtswhere today they are generally thought to represent a significant part of the caseload problem-without any sacrifice in the law's efficacy. Of course, had Congress decided to vest the EEOC with adjudicatory powers, it would have had to staff and finance the agency differently from the outset. At the time, unfortunately, there was no one to undertake the analysis that Donohue and Siegelman have undertaken only in hindsight. ${ }^{62}$

It is easy to cite other examples where an ounce of this sort of prevention might have avoided the need for a pound of cure. ${ }^{63}$ Once a law is enacted, however, it becomes difficult to change the structure of jurisdiction (for reasons explained in Part I). By establishing an agency to conduct qualitative analyses prior to the enactment of legislation, judicial resources may be used to better advantage. The agency would act in a support capacity, performing the necessary evaluations of projected caseloads and making recommendations about the most efficient way to structure jurisdiction.

Qualitative resource estimation is not all that such an agency could do, for even as applied to quantitative caseload analysis-that is, predicting the number of cases-the objections to forecasting are overstated. One can take almost any task, break it down into as many subtasks as imagination allows, maximize the risk of error for each subtask, and in this way prove that the task cannot possibly be performed. When I was a law student, Richard Epstein used this technique to persuade my torts class that driving a car was impossible. No one, he argued, could simultaneously track the car's speed; watch the road for people and other cars; read, translate, and react to traffic

62. The full story is more complicated. Proposals to give the EEOC adjudicatory powers were made in 1964 but were defeated because of fears that the agency would be too pro-employee. See Frances J. Vaas, Tille VII: Legislative History, 7 BC Indust \& Comm L Rev 431, 436-37, 450-54 (1966). Arguments about resource allocation might have had some impact on this debate, but probably would not have changed the outcome. The example thus underscores the limits that politics will set on any planning mechanism. It does not follow that political factors will always dominate. Unfortunately, because the analysis required for any particular legislation is sufficiently complex to be beyond the scope of this article, my choice of illustrations is limited to those few areas where the work has already been done and can be summarized. This, of course, helps underscore the need for an agency of the type I propose.

63. For instance, Part I also mentions the problem of jurisdiction over civil tax disputes, where more careful planning could have avoided much wasteful litigation. See note 32 and accompanying text. 
lights and road signs; and coordinate finger, wrist, forearm, and shoulder muscles with toe, foot, calf, and thigh muscles to control the steering wheel and the pedals in response to all these stimuli. This example basically describes the attack on caseload forecasting.

But of course we can drive cars. And we can make caseload predictionsperhaps not as well as we drive, certainly not perfectly, but well enough to obtain substantial information to use in making policy. Even the harshest critics of caseload prediction concede that some accurate forecasting is possible, ${ }^{64}$ and proponents are much more optimistic. ${ }^{65}$ Social scientists and policy analysts have already developed a variety of techniques for making predictions: mathematical models that take multiple variables into account, supplemented by expert opinions to anticipate surprise events; ${ }^{66}$ computer simulations; ${ }^{67}$ case flow and resource consumption models; ${ }^{68}$ demonstration projects; ${ }^{69}$ and other forms of structural modeling. ${ }^{70}$ The explanation of how such techniques work is a topic well beyond the scope of this article (and the expertise of its author). Suffice it to say that these methods have been and can be used to make some successful caseload forecasts.

Having said that, I must add a word of caution. Critics may overstate the case in contending that methodological difficulties make caseload forecasting impossible, but the difficulties are real. Existing techniques are crude, and considerable refinement is needed before we can confidently predict how many cases of a particular type are likely to follow from new legislation. Indeed, we may never be able to make such predictions with precision.

But then, precision is not really necessary. Particularly as Congress becomes more reluctant to relieve caseload pressures by creating new judgeships, the importance of quantitative caseload estimates will diminish. The real utility of quantitative analysis may be to supplement qualitative analysis. It is important to know that the mix of cases under new legislation is likely to be predominantly of one type rather than another, and a sense of the relative magnitude of any differences would be still more helpful. This much we can do. Perhaps we cannot determine whether the mix will consist of 12,535 cases of one type and 3,672 cases of another, or 11,123 and 5,074 , but

64. See Boyum \& Krislov, Forecasting the Impact of Legislation on Courts at 3 (cited in note 1); Kerwin, Never the Twain Shall Meet at 173, 176 (cited in note 27).

65. See Goldman, Hooper \& Mahaffey, 5 J Legal Stud at 201 (cited in note 41); Davis \& Nejelski, 62 Judicature at 18 (cited in note 27); Gallas, Judicial-Impact Statements at 158 (cited in note 27).

66. See Goldman, Hooper \& Mahaffey, $5 \mathrm{~J}$ Legal Stud at 201 (cited in note 41). This technique is not only the most technically complex, but also the most ambitious and successful experiment in caseload forecasting. The authors developed several models and tested them against real data, concluding that "[t]he proposition upon which this forecasting effort was based is sound; forecasts of district court caseload can be calculated by the use of social, political, demographic, and economic indicators." Id at 233.

67. See Paul Nejelski, Computer Simulation: An Aid to Court Study, 55 Judicature 17 (1971).

68. See Kerwin, Koehler \& Dawson, 3 Policy Stud J at 1074-76 (cited in note 51).

69. See Barbara Curran, Legal Services for Special Groups (Am Bar Found Res Contrib No 1, 1972) (describing various projects); Boyum \& Krislov, Forecasting the Impact of Legislation on Courts at 87 (cited in note 1 ).

70. See Boyum \& Krislov, Forecasting the Impact of Legislation on Courls at 95-97 (cited in note 1). 
that information is not essential. In any event, while we must accept the fallibility of efforts to estimate caseloads and the risk of error inherent in such forecasts, it would be foolish to conclude that because we cannot estimate perfectly, we should not estimate at all: "In the land of the blind, the oneeyed are kings." Nor will we remain even partially blind for long, for as we gain experience with caseload forecasting techniques, our vision is likely to improve.

\section{B. Reviewing Decisions of the Courts and the Executive Branch}

An agency to examine legislation while it is under development may improve Congress's ability to use judicial resources efficiently, but it is not enough. No matter how well this agency does its job, some statutory gaps, glitches, and ambiguities will escape notice and make their way into the world to cause trouble for courts and litigants. ${ }^{71}$ In addition, as explained below, ${ }^{72}$ the proposed agency would not review all pending legislation, and some laws that are overlooked will undoubtedly have unanticipated effects on the federal caseload. Finally, there surely will be instances when the agency's recommendations for structuring federal jurisdiction turn out badly and require correction.

More importantly, not every problem in the judicial system results from action taken (or not taken) when laws are enacted. Interpretations by other branches often alter legislation in ways that have profound consequences for the federal courts. By recognizing an implied cause of action, for example, the courts may unexpectedly change the anticipated level of enforcement and increase the volume of litigation. ${ }^{73}$ Similar consequences follow from judicial decisions expanding liability under statutes that were formerly read narrowly. Take the Supreme Court's decision in Monroe v. Pape, ${ }^{74}$ which interpreted 42 U.S.C. section 1983 to impose liability for deprivations of constitutional rights by state officers even if the officers' actions were not authorized or were forbidden by state law. Prior to Monroe, litigation under section 1983 was infrequent; one commentator reports finding only nineteen cases in the U. S. Code annotations during the statute's first sixty-five years. ${ }^{75}$ Since Monroe, section 1983 litigation has grown like Topsy, and cases brought under this statute constitute a much larger portion of today's federal docket. ${ }^{76}$ An even

71. See Henry J. Friendly, The Gap in Lawmaking-Judges Who Can't and Legislators Who Won't, in Henry J. Friendly, ed, Benchmarks 41-64 (U Chi Press, 1967); Ruch Bader Ginsburg \& Peter W. Huber, The Intercircuit Committee, 100 Harv L Rev 1416, $1421-23$ (1987); Proceedings of the 49th Judicial Conference of the District of Columbia Circuit, 124 FRD 241, 319-21 (1988) ("DC Circuit Proceedings").

72. See text accompanying note 99.

73. See, for example, Superintendent of Insurance v Bankers Life E Cas. Co., 404 US 6, 13 n9 (1971) (private cause of action under $\S 10(\mathrm{~b})$ of the Securities Exchange Act); J.I. Case Co. $v$ Borak, 377 US 426 (1964) (private cause of action under $\$ 14$ (a) of the Securities Exchange Act).

74. 365 US 167 (1961).

75. Note, Limiting the Section 1983 Action in the Wake of Monroe v Pape, 82 Harv L Rev 1486, 1486 n4 (1969).

76. See 1988 Annual Report of the Director of the Administrative Office of the United States Courts, Table C-1. Other commentators suggest that the growth in $\S 1983$ litigation is less 
better example may be judicial decisions interpreting the Racketeering Influenced and Corrupt Organizations Act ("RICO”) to reach non-traditional racketeering activity by legitimate businesses that commit more than one predicate act. ${ }^{77}$

Nor are judicial interpretations the only source of new problems for the federal courts. Changes in executive policy may have equally dramatic effects. The number of cases brought by social security disability claimants rose dramatically in the early 1980 s as a result of policies instituted by the Social Security Administration ("SSA"). ${ }^{78}$ Intended to reduce the welfare rolls, these new policies instead provoked a phenomenal number of claims challenging SSA's determinations. This influx did not abate until the mid1980 s, when SSA altered some of its policies and Congress enacted legislation overruling others. Another example of executive action with dramatic consequences for the federal caseload is the President's recently declared "war on drugs." Because criminal cases take more time (particularly trial time) than civil cases, and because the Speedy Trial Act mandates processing criminal cases quickly, the anticipated increase in prosecutions from this effort will very likely impede civil litigation. According to some judges, their time will soon be spent exclusively on criminal matters. ${ }^{79}$

Of course, Congress hardly needs a new agency to inform it of such well known problems. But these are just illustrations. The vast majority of decisions that affect the federal caseload are less newsworthy and receive no publicity or fanfare. This does not mean that these decisions do not create real problems, and the cumulative effect of many small problems can be devastating. At present, however, there is no one responsible for reviewing decisions of the courts and executive branch for their impact on judicial administration. ${ }^{80}$ One might expect this task to be performed by congressional staff, but these personnel have too many other responsibilities to stay current on every decision by every court or administrator on issues within their purview. ${ }^{81}$ As a result, decisions go unnoticed until the problems they create have become serious. By then, various interest groups have

spectacular than is commonly assumed. See, for example, Theodore Eisenberg \& Stewart Schwab, What Shapes Perceptions of the Federal Court System, 56 U Chi L Rev 501 (1989); Theodore Eisenberg \& Stewart Schwab, The Reality of Constitutional Tort Litigation, 72 Cornell L. Rev 101 (1987). Moreover, not all of the growth is attributable to Monroe $v$ Pape; much of the credit goes to decisions that broadened the scope of constitutional protections and fostered a sympathetic environment for such claims. Be that as it may, judicial interpretations that expanded the scope of this statute clearly increased the amount of litigation. The same thing may be said of judicial decisions holding other civil rights statutes applicable to wholly private conduct. See, for example, Jones v. Alfred H. Mayer Co. 392 US 409 (1968) (42 USC § 1982 (1988)); Runyon v McCrary, 427 US 160 (1976) (42 USC 1981 (1988)).

77. See, for example, Sedima, S.T.R.L. v Imrex Co., 473 US 479 (1985).

78. See Levy, 1990 BYU L Rev at 478-509 (cited in note 33).

79. See Subcommittee Report on the Role of the Federal Courts at 45-46 (cited in note 4).

80. Katzman, ed, Judges and Legislators at 7 (cited in note 30).

81. An informal survey by one commentator found that while congressional staff members tend to be aware of major Supreme Court decisions, they have little knowledge of other decisions. See DC Circuit Proceedings at 323-24 (cited in note 71). 
invested in the new status quo and have acquired a stake in preserving it; as explained in Part I, getting Congress to act becomes quite difficult.

Identifying a problem quickly and routing it to the appropriate committee in Congress may make it easier to obtain corrective action, since fewer groups will have a substantial interest in blocking change. Accordingly, a second function of the planning agency could be to review decisions of the other branches and apprise Congress of those with significant implications for judicial operations. While the forces that impede reform may make revision of judicial and executive decisions more difficult than preenactment planning, there is still reason to expect significant benefits.

This idea is not new, Justice (then Chief Judge) Cardozo proposed creating a "Ministry of Justice" to review judicial decisions in 1921, attributing the idea to earlier writings by Roscoe Pound and Jeremy Bentham. ${ }^{82}$ Cardozo's proposal was part of a broader movement that led to the establishment in most states of judicial conferences and in many states of law revision commissions. ${ }^{83}$ The former are typically responsible for running the state's judicial bureaucracy and for updating its rules of procedure and evidence. The latter more closely approximate the kind of entity I am proposing for the federal system in that state law revision commissions are usually responsible for examining laws and judicial decisions and making recommendations for reform to the legislature.

Experience with state law revision commissions has generally been good, and several states, particularly New York and California, have had notable success. ${ }^{84}$ The New York Law Revision Commission was responsible for that state's adoption of the Uniform Commercial Code ("UCC"), 85 which helped create momentum for the UCC's nationwide acceptance. The California commission produced an evidence code that has been the basis for practically all subsequent reform in the field. ${ }^{86}$ In addition to such large projects, both the New York and California Law Revision Commissions have made many less

82. Benjamin N. Cardozo, A Ministry of Justice, 35 Harv L Rev 113, 114 (1921), citing Roscoe Pound, Juristic Problems of National Progress, 22 Am J Society 721, 729, 731 (1917); John Bowring, ed, 9 The Works of Bentham 597-612 (Simpkin Marshall, 1843). The proposal to create such a ministry apparently originated in an 1828 speech on law reform by Lord Brougham. It was then picked up by Bentham in his draft for a constitutional code, and in 1856 was offered in the House of Commons as a resolution to create a "Department of Public Justice." See Friendly, The Gap in Lawmaking at 59 (cited in note 71 ).

83. Russell R. Wheeler \& Donald W. Jackson, Judicial Councils and Policy Planning: Continuous Study and Discontinuous Institutions, 2 Just Sys J 121, 125-30 (1976).

84. See, for example, Survey, The District of Columbia Law Revision Commission, 34 Cath U L Rev 1309 (1985); Henry G. Fins, The Illinois Law Revision Commission, 29 DePaul L Rev 443 (1980); John W. MacDonald, The New York Law Review Commission: The Past and the Future, 13 SLU L Rev 258 (1968); Ferdinand F. Stone, The Louisiana State Law Institute, 4 Am J Comp L 85 (1955); Ralph N. Kleps, The Revision and Codification of Califormia Statutes 1849-1953, 42 Calif L Rev 766 (1954); Bernard L. Shientag, A Ministry of Justice in Action: The Work of the New York State Law Revision Commission, 22 Cornell L Q 183 (1937).

85. MacDonald, 13 SLU L Rev at 260 (cited in note 84).

86. See Recommendation of the California Law Revision Commission Proposing an Evidence Code, in 29B Calif Code Ann xxiii (West, 1966) (originally published as Report and Recommendation of the California Law Review Commission, Jan 1965). 
prominent, but still useful, recommendations. Through 1984, 163 of 185 recommendations made by the California Law Revision Commission had been adopted in whole or in part by the state's legislature. ${ }^{87}$ In its first twenty-three years, the New York Law Revision Commission submitted 315 recommendations dealing with 245 subjects, of which 181 were enacted. ${ }^{88}$ These successes have led other commentators-among them judges, legislators, and executive officials-to recommend creating a law revision commission for the federal government. ${ }^{89}$

By also functioning as a law revision commission, a planning agency could do still more to facilitate efficient use of judicial resources. ${ }^{90}$ Moreover, having a single agency both review pending legislation and track its postenactment implementation should generate synergies that improve the agency's performance. Caseload forecasting is a relatively new idea. Over time, the new body would gain experience that would improve the quality of its recommendations. This learning process would be aided immeasurably if the persons responsible for forecasting future growth were also responsible for reviewing how courts respond in practice.

\section{Improving Communication Between the Branches}

A third potential function concerns communication between Congress and the other branches of government. Even a well-budgeted, fully staffed planning agency will miss some problems that arise in the course of administering federal law. These problems are not likely to be overlooked by those who must live with them, however. The judges and executive branch officials responsible for day-to-day administration are thus an invaluable source of information about how to improve the judicial system. Yet communication between the branches on such matters is sporadic and unsatisfactory. Justice Cardozo wrote in 1921:

[t]he means of rescue are near for the worker in the mine. Little will the means avail unless lines of communication are established between the miner and his rescuer. We must have a courier who will carry the tidings of distress to those who are there to save

87. 17 Cal L Revision Commission Reports 829-43 (1985).

88. Friendly, The Gap in Lawmaking at 59-60 (cited in note 71). In addition, the New York Law Revision Commission served as the model for similar commissions in Australia and the Sudan. See Carolyn Gentile, Historical Overview, in 1985 New York L Revision Commission 38, 47.

89. See, for example, The Bork Report at 16-17 (cited in note 41); Ginsburg \& Huber, 100 Harv L. Rev at 1430-32 (cited in note 71); Ruth Bader Ginsburg, A Plea for Legislative Reziew, 60 Cal L Rev 995 (1987); DC Circuit Proceedings at $321-27$ (cited in note 71); A Bill to Establish an Intercircuit Panel, and for Other Purposes, Hearings on S 704 before the Subcommittee on Courts of the Senate Judiciary Committee, 99th Cong, 1st Sess 36 (1985) (letter from Justice John Paul Stevens, Oct 25, 1983); Friendly, The Gap in Lawmaking at 58-64 (cited in note 71); Katzman, ed, Judges and Legislators at 126-27, 176 (cited in note 30); Harvard Student Legislative Research Bureau, The Law Revision Commission, 3 Harv J Legis 361 (1966).

90. My proposal differs from the typical law revision commission in some important respects While the typical state law revision commission may propose any kind of substantive reform, my proposed agency would focus on inefficiencies in the deployment of federal judicial resources. Furthermore, while most state law revision commissions focus on obscure statutory or common law doctrines, my proposed agency would more frequently be involved in current matters with high profiles. 
when the signals reach their ears. Today courts and legislature work in separation and aloofness. The penalty is paid both in the wasted effort of production and in the lowered quality of the product. ${ }^{91}$

This statement remains true nearly seventy years later. Members of Congress and their staff say that more input from judges is desirable. ${ }^{92}$ Yet judges and executive officials complain constantly that they are unable to communicate their concerns to Congress. ${ }^{93}$ The complaint is not that doors in Congress are closed, but rather that the judges and officials do not know whom to contact. I should add a caveat: the complaint about not knowing whom to contact does not include budgetary or staffing problems, or controversial issues like habeas corpus in capital cases. Rather, the gap in communication exists for less prominent issues, especially technical statutory issues. On these matters, judges and executive branch officials are apparently unsure whom to inform and so tend to say nothing.

A third function of a planning agency thus could be to facilitate communication between Congress and the other branches by acting as liaison. If a judge renders a decision that he or she believes calls for a legislative response, or if an executive official comes across a problem and believes Congress ought to solve it, the judge or official could contact the agency, which would be responsible for referring the matter to the appropriate committee in Congress. Perhaps this task of referring issues could be coupled with a requirement to research them and make a recommendation. This procedure would save considerable time by weeding out frivolous suggestions. In addition, like the law revision function, processing and reviewing complaints from other branches would contribute to the education of agency staff on how laws work in practice. ${ }^{94}$

\section{Structure of the Agency}

While the discussion in Parts I and II explains the usefulness of better planning in preserving judicial resources, one may legitimately ask whether this function requires a new agency. Why not utilize existing bodies like the Office of the Law Revision Counsel in Congress, or the Office of Legislative Affairs and the Office of Legislative and Public Affairs in the legislative and judicial branches? If the problem is lack of resources, Congress can simply provide these agencies with additional funding.

But the problem with existing institutions is more fundamental than lack of resources. None of these entities currently conducts the kind of caseload analysis and review of decisions that I propose. None of them is staffed by

91. Cardozo, 35 Harv L Rev at 113 (cited in note 82).

92. DC Circuit Proceedings at 324 (cited in note 71 ).

93. See, for example, the essays by Frank M. Coffin, Roger H. Davidson \& Hans A. Linde in Katzman, ed, Judges and Legislators (cited in note 30 ).

94. Communication between the branches could be improved in other ways as well. Better understanding of how different branches function might be facilitated through simple face-to-face meetings of judges, members of Congress, and their staffs. 
persons with the training or experience necessary to generate and evaluate the data. The Office of the Law Revision Counsel does no analytical work. As for the Legislative Affairs Offices in the executive and judicial branches, these are basically lobbies for their respective branches, and nothing would cripple a planning agency faster than to be seen as simply another lobby. Consequently, none of these existing entities provides an appropriate foundation upon which to build a technical support organization.

But what chance does a new agency have to succeed? Most observers are understandably pessimistic about proposals for reform that call for expanding the federal bureaucracy-assuming that any new agency is likely to become the tool of some interest group; an independent political force pursuing its own self-seeking agenda; or powerless, meaningless, and ignored. But while it is always possible that an agency will fall victim to one of these forms of administrative failure, it is not inevitable. Moreover, we can reduce the risks by structuring the agency properly.

The most important question is, in which branch should the new planning agency be located? This issue is controversial, particularly for judges. The judicial bureaucracy is extremely protective of its position as Congress's primary source of information about the needs of the courts, and it strongly opposes the creation of a judicial planning agency outside its control.95 Nonetheless, I believe the planning agency should be located in the legislative branch. As Judge Friendly observed, "[i]t would seem elementary that an agency whose task is to [help] formulate legislation . . . should be attached to the legislature." 96 Congress is far more likely to heed recommendations from a body within the legislature than from the other branches. Furthermore, placing the new agency in the legislative branch will produce closer working relationships and greater trust between its staff and that of Congress, thereby lending credibility to the agency's work. Support for these conclusions is demonstrated by the success of existing support agencies in Congress, such as the Congressional Research Service, the Office of Technology Assessment, and the Congressional Budget Office. Experience with state law revision commissions also suggests that such bodies work better when located in the

95. The Federal Courts Study Committee recommended creating an "Office of Judicial Impact Assessment" similar to the proposal made here. See Report of the Federal Courts Study Committee at 91-93 (cited in note 3). This recommendation originated in the Committee's Subcommittee on the Role of the Federal Courts and their Relation to the States, of which I was the reporter. The subcommittee recommended establishing the agency within Congress, and this aspect of the proposal evoked strong opposition from the Administrative Office and the Judicial Conference. Indeed, these bodies may have shown more interest in blocking this proposal than in any other aspect of the Committee's work. In the end, the Committee modified the Subcommittee's recommendation to locate the new planning body within the Judicial Conference. Id.

96. See Friendly, The Gap in Lawmaking at 62 (cited in note 71). See also Report of the Federal Courts Study Committee at 92-93 (cited in note 3) (additional views of Congressman Robert W. Kastenmeier). The location of the agency seems to be limited to either the legislature or the judiciary. Little interest exists from the executive branch in assuming these new responsibilities, and general agreement exists that it is the least appropriate location for a judicial planning agency. See Hans A. Linde, Observations of a State Court Judge, in Katzman, ed, Judges and Legislators at 117,127 (cited in note 30 ). 
legislative branch. This placement, for example, appears to be one of the factors distinguishing the successful New York and California commissions from their less successful counterparts in other states. ${ }^{97}$

While placement of the planning agency may have some bearing on its effectiveness, the best guarantee of success is good work. A planning agency is most likely to succeed if it establishes a reputation for producing quality work. As explained in Part II, one reason for centralizing the various functions in a single agency is that cumulative experience with forecasting and review should lead to improved methodology and a better understanding of the data and their limits. ${ }^{98}$ There are, moreover, a number of additional steps that may further improve the quality of the agency's work.

The single most important consideration in this regard is staff. To succeed, the planning agency must have a professional staff with expertise in the various functions to be performed. Caseload forecasting requires training in economics, social science, or statistics in order properly to identify and analyze the social, political, economic, or demographic factors relevant to particular legislation. It also requires the insight of someone familiar with law and courts. Legal training is needed for the agency's review functions, which require understanding the implications of judicial opinions for future cases. The agency staff must therefore include persons from different disciplines who can work together on various projects. The more highly qualified the staff, the more likely the agency is to perform impressively.

While Congress obviously must oversee the agency, its members should neither participate directly in the agency's work nor be responsible for day-today operations. The sensitive nature of the agency's assignment makes it susceptible to political forces that may want either to control or to impede its conclusions. Such problems cannot be avoided altogether, but they can be minimized by establishing the agency as an independent, technical support group.

Another important consideration is the scope of the agency's responsibilities. One of the most telling criticisms of Chief Justice Burger's proposal for court impact statements was that requiring such statements for every proposed bill would lead to pro forma statements of little informative value. ${ }^{99}$ Thousands of bills are introduced in a typical session of Congress, most of which never pass and would have little or no impact on the federal courts if they did. To require the same level of review for all these bills would swamp the planning agency with useless work. A better approach would be either to give all bills a cursory examination to determine which may potentially have a significant impact on the federal courts (something akin to the Supreme Court's certiorari review), or to wait until a committee or subcommittee of Congress has indicated real interest in proposed legislation.

97. See Friendly, The Gap in Lawmaking at 62 (cited in note 71); Subcommittee Report on the Role of the Federal Courts at 151 (cited in note 4).

98. See Davis \& Nejelski, 62 Judicature at 129 (cited in note 27).

99. See note 45 and accompanying text. 
Either approach would free agency staff to concentrate on the laws most likely to benefit from detailed review.

A third concern relates to the state of the art. Caseload planning is a relatively new idea, and many techniques are still in the early stages of development. While these techniques will continue to improve, much of this work will be done outside the legislative process, in the academy or in other parts of government. A new planning agency should have access to this technology as it develops. The best way to do this is to authorize the agency to employ outside experts to work with its staff on particularly difficult projects. This method has several advantages. Contracting out will allow Congress to keep the agency small, making it easier to maintain high professional standards and avoid bureaucratization. It will further the ongoing education of staff members and improve the quality of their work. It will give staff members a chance to work closely with other experts in their respective fields and thus make working for the agency more attractive. Finally, and most importantly, it will encourage the kind of experimentation that is likely to improve our ability to do reliable caseload forecasting and planning.

The picture that emerges is of an agency that resembles the Office of Technology Assessment ("OTA"). This is no accident. Like OTA, the proposed agency is intended to assist Congress by conducting technical evaluations requiring special expertise. As with OTA, this assistance is best provided by a small, highly qualified staff that has access to research being done outside the legislative process. And like OTA, the proposed agency will not revolutionize the legislative process, but it can improve legislation on issues within its purview.

\section{IV}

\section{Conclusion}

Determining the most efficient way to structure jurisdiction under particular legislation is neither easy nor obvious, and to do it well requires experience and expertise. At present, such determinations are seldom made or are made haphazardly. Caseload planning is a difficult and inexact science. But why remain blind when we can improve our vision? Instead, we should create an agency to help us see. Such a body will not solve all our problems, but it will provide some improvement in the quality of legislation and some savings in judicial resources-more than enough, I am sure, to justify its costs. 
